\title{
RESEARCH NEEDS OF PEATLAND
}

\author{
BY J. K. MCEWEN 1
}

Oxf. 114.3, 182.2

\section{ABSTRACT}

Responsible forecasts indicate that Canada will have an increased demand for forest products in the future. To maintain our present black spruce forests on their present sites, to increase the growth rate and to extend our forests requires an increased knowledge of the organic sites on which black spruce grows. We should be gathering this information now. A knowledge of the results of European research can save us much time and money.

There were two reports during 1966 of considerable interest to foresters. The 1966 volume of Unasylva considered many aspects of forestry and projected increasing demands for forest products. The chief suppliers for the future market, according to the authors, were to be the U.S.S.R., the tropical countries and Canada. On a domestic scale, the National Forestry Conference at Montebello (Beall, 1966) had a similarly optimistic view of our potential future markets.

It would be to our great advantage if we could ensure rapid establishment of regeneration and increase the rate of growth of our forests. Black spruce (Picea mariana (Mill.) B.S.P.), as a major species, merits special consideration. Since it is characteristically found on lowland sites, knowledge of these sites is a prerequisite to better management practices.

Bogs $^{2}$ and fens ${ }^{2}$ occur throughout Canada and constitute about a tenth of our land area. The Hudson Bay Lowland, which extends into three provinces, is the largest uninterrupted expanse of peat ${ }^{2}$ in the world and occupies one quarter of the land area of Ontario. Immediately south of this, large areas of peat occur discontinuously wherever there is impaired drainage. As well as in the treeless bogs and fens, organic materials constitute the upper layer of soil where stunted unmerchantable black spruce occurs and on most of the area where our commercial black spruce is located.

The development of peatland has been a result of a number of factors. The great expanse of bog and fen in the Hudson Bay Lowland developed as primary paludification after the marine invasion which accompanied the last glacial retreat. As the land slowly emerged from the sea, aquatic plants were succeeded by semi-aquatic forms which, in turn, gave way to terrestrial forms. Due to the very gradual slope of the land and to the moist climatic periods which succeeded the xerothermic period (Potzger and Courtemanche, 1956), water accumulated on the land, aeration was interrupted and the surface vegetation, on dying, did not decompose. While the organic blanket was thin, the influence of the inorganic soil below was such as to support a sedge or grass fen condition with some birch (Terasmae and Hughes, 1960). With an increasing depth of organic material, less nutrients were available and the upper layers became more acid and less fertile bog.

It should be noted, however, that even now a large part of the Lowland

\footnotetext{
${ }^{1}$ Research Scientist, Ontario Department of Lands \& Forests, Port Arthur, Ontario. ${ }^{2}$ See glossary at end.
} 
is fen rather than bog. Where good drainage occurs, even as far north as $53^{\circ}$ latitude, 110 -year-old spruce trees (presumably white spruce) have attained diameters at breast height of 34 inches and heights of 100 feet (Sjörs, 1959). Due to good drainage conditions, the margins of the rivers customarily show well-developed forest, while a hundred yards away from the rivers, the muskeg holds sway.

South of the Lowland, the development of organic soils has not been from this primary paludification. In many cases it has resulted from deposits in the free, but slow-moving, water in ponds or lakes. In such bodies, the water was originally well supplied with oxygen and mineral nutrients carried down from the surrounding terrain. Aquatic flora and fauna appeared and their remains, together with coprogenic particles, descended to the bottom. On the bottom, a blending with inorganic material of the lake or pond bed resulted in a well-decomposed and humified deposit. This early formation was not peat. With further deposition of material, the bed built up and sub-aquatic plants appeared. Gradually, with this increasing depth, the movement of air and nutrients was curtailed and the deposit was then less decomposed and less rich. In time, the bed rose above the water surface. Sedges and rushes occupied the area, then herbaceous plants, shrubs and trees took over.

On these hydroseral fens and on the fens which resulted from primary paludification, further growth leaves continually more of the nutrients locked in the undecomposed deposit of dead plants and the isolation from mineral soil becomes more complete. Grasses, mosses and heath plants, which have low nutrient requirements, become dominant and the area may in time develop into a slightly convex or raised bog.

Yet another type of bog formation occurs where abundant rainfall leaches nutrients from the upper inorganic layer. Ericaceous shrubs and conifers add to the soil's acidity and at a certain point the aluminum and iron salts percolate through the soil and are deposited at a lower level as a hard pan. Over this condition, excess water accumulates and peat begins to form (Jacks, 1959).

The development of peat soils can occur whenever the water balance suffers a major disturbance over extensive areas of essentially level forest, such as clear-cutting or fire. When transpiration and evaporation are reduced, water and organic soils accumulate. If the site is sufficiently rich, a temporary crop of alder and willow takes over, which restores the water balance and which is succeeded in time by spruce. If the site is poor, sphagnums and ericaceous plants enter the succession. The abundant moisture and the partial shade afforded by the ericaceous plants offer optimum conditions for sphagnum growth and the peat begins to accumulate to the further detriment of the site. A similar development can also be seen in over-mature spruce stands where the crown canopy is opening up due to stand mortality. (Siren, 1955).

Secondary paludification may start from a basin bog or a muskeg area. The combination of sphagnum and ericaceous plants may move outward and even ascend appreciable slopes. In the course of its extension, the sphagnum inundates advance growth and arrests the growth of larger trees. 
The degree of slope which can be thus paludified will vary with altitude and with latitude. Gorham (1957), for example, mentions peat 11/2 metres in depth on a 20 percent slope in the U.K. Paludification can be a serious problem to man when he interfers with the evaporation and transpiration from a forested area. There is considerable information available to us. There is, for example, in Gorham (1957) an excellent discussion of the factors which are responsible for peat formation-particularly low temperatures, high precipitation, low relief and acid sites. Heinselman, 1963, not only deals with the causes of paludification but also discusses in considerable detail the formations which have developed on the flat beds of former Lake Agassiz in Minnesota. Sjörs was handicapped in 1957 in the matter of access on foot to the wettest sites on the Hudson Bay Lowland but his field work and his aerial reconnaissance, linked with his broad knowledge of peatland ecology, have added much to our fund of knowledge.

Since organic soils make up such a large portion of our land and since they have, in many cases, a high potential for forest growth, we will be more and more concerned with them. While we have done less with such sites than any other country possessing peatlands, we can save time and expenditures by adapting the accumulated knowledge from abroad to our use.

In Finland, for example, Heikurainen and Huikari (Heikurainen, 1960 a) have classified Finnish peatlands into 28 types and described their suitability for drainage. In Russia, Pyavchenko (1959) describes in considerable detail three types of forest in each of the three nutrient classes - eutrophic, mesotrophic and oligotrophic--and records the site classes which will result from forest drainage. Both the Finnish and the Russian studies deal with tree species which differ in their requirements from our commercial species but the studies do provide us with useful information.

In the United Kingdom, which lacked native spruce since the last glacial period, much experimental work has been carried out with exotics (largely North American in origin) on peatlands (Zehetmayr, 1954).

Successful tree growth on peatlands requires not only drainage but the presence of nutrients in adequate amounts and available form. Some fen sites will require no extra nutrients. The bogs however will certainly need supplements. Phosphorus is always deficient and its lack is totally limiting to tree growth. A deficiency of potassium has also been found to retard tree growth some years after stands had been established by the use of phosphorus. Although most nitrogen is in an unavailable organic form in peat, there seems to be enough mineralized for satisfactory tree growth (Binns, 1960).

Nutrient studies on peatland have been conducted for many years in Europe. Much work has been done in this field in Britain in connection with their plantings on treeless peats and heaths (Zehetmayr, 1954, 1960; Binns, 1960). Workers in Finland have carried out nutrient studies over a number of years. Recently as a resul: of these studies, fertilization has been instituted as a standard practice in peatland afforestation. Heikurainen (1960 b) discussed the role and availability of the various elements in some detail.

I would forecast that we will, before long, be as concerned about these organic sites as are all other nations with similar climatic conditions. We 
could expand our knowledge of aerial photography with respect to the interpretation and correlation of vegetational patterns with fertility. We could in the early stages define certain rudimentary features of slope and ground cover which, together with $\mathrm{pH}$ readings and minimal soil analyses, would indicate the site potential.

With time and experience we could stop the degradation of highly productive sites by paludification. We could reverse this trend and, as the peat wastes away, the sites would become continually more profitable.

Our future studies should develop along two main lines: first, to prevent the massive development of sphagnums on cut-overs by holding down the accumulation of water and second, to reduce the sphagnum overburden where it now exists and release locked nutrients for faster tree growth.

\section{GlosSARY}

Bog - an area of peatland low in nutrients and acid in $\mathrm{pH}$, normally covered with sphagnum and ericaceous sub-shrubs.

Fen - an area of peatland, rich in nutrients, normally neutral or basic in $\mathrm{pH}$, sometimes tree-covered and usually carrying sedges and herbaceous plants.

Mire - a general term for both fen and bog types of peatland.

Paludification - conversion of dry land to mire.

Peat - an organic deposit, low in inorganic material, produced under wet, anaerobic conditions.

\section{REFERENCES}

ANON. 1966. Wood, world trends and prospects; the pulp and paper industry, Unasylva $20(1-2): 80-81$

BARRY, T. A. 1954. Some considerations affecting the classification of the bogs of Ireland and their peats. Irish Forestry, Vol. XI, No. 2.

BEALL, H. W. 1966. 'The National Forestry Conference', Woodlands Review. p. 431 Sept., 1966.

BINNS, W. O. 1960. Scottish soils in relation to afforestation. Institute of Biology Journal, Vol. 7, No. 1.

GORHAM, E. 1957. The development of peatlands. Quarterly Review of Biology, Vol. 32 (2) : $145-166$

HEIKURAINEN, L. 1960a. Swamp forestry research in Finland. Silva Fennica 108, 1960. Helsinki.

HEINSELMAN, M. L. 1963. Forest types, bog processes and peatland types in the glacial Lake Agassiz region, Minnesota. Ecological Monographs 33 (4):327-374.

JACKS, G. V. 1959. Soil, Nelson and Sons Ltd., New York.

PIAVCHENKO, N. I. 1959. Typing of paludifed forests for the purpose of drainage (in Russian). Trud. Inst. Lec. Vol. XLIX, Moscow.

POTZGER, J. E. and A. COURTEMANCHE, 1959. A series of bogs across Quebec from the St. Lawrence valley to James Bay. Canadian Journal of Botany, 34:473.

SIRÉN, G. 1955. The development of spruce forests on raw humus sites in Northern Finland and its ecology. Acta for fenn. 62 (4)

SJORS, H. 1959. Bogs and fens in the Hudson Bay Lowlands. Arctic, 12 (1): 1-19.

TERASMAE, J. and O. L. HUGHES, 1960. A palynological and geological study of Pleistocene deposits in the James Bay Lowlands, Ontario. Bulletin 62, Geological Survey of Canada, Dept. of Mines and Technical Surveys.

ZEHETMAYR, J. W. L. 1954. Experiments in tree planting on peat. U.K. Forestry Commission, Bull. No. 22.

$$
\text { No. } 32 \text {. }
$$

